HORTSCIENCE 27(7):826-829. 1992.

\title{
Inheritance of Cold Germinability in Muskmelon
}

\author{
Mark G. Hutton ${ }^{1}$ and J. Brent Loy \\ Department of Plant Biology, University of New Hampshire, Durham, \\ NH 03824 \\ Additional index words. Cucumis melo, low-temperature germination, cytoplasmic \\ inheritance
}

Abstract. A cold-germinable (CG) line of muskmelon (Cucumis melo L.) derived from PI 126156 was crossed to a noncold-germinable (NCG) line derived from 'Delicious 51'. Seed of parents and reciprocal $F_{1}, F_{2}$, and $B C$ families were incubated for 14 days on absorbent wadding in petri dishes at $15 \mathrm{C}$. Days elapsed to radicle emergence among progeny from reciprocal crosses and segregating populations indicated the existence in the CG line of a cytoplasmic factor and recessive nuclear genes for cold germinability. Based on $F_{z}$ and $B C$ segregation, it appears that at least three or four recessive genes confer cold germinability. High levels of cold germinability in a seed population required the presence of both the cytoplasmic factor and nuclear genes for cold germinability.

Fluctuating soil temperatures often exist during the early part of the growing season in many regions. Under low temperatures, germination and seedling establishment of many warm-season crops, such as muskmelon, are severely hindered. Because melon seedlings are usually transplanted into the field in northern latitudes, considerations for

Received for publication 19 Dec. 1991. Accepted for publication 13 Jan. 1992. Scientific Contribution no. 1729 from the New Hampshire Agricultural Experiment Station. The cost of publishing this paper was defrayed in part by the payment of page charges. Under postal regulations, this paper therefore must be hereby marked advertisement solely to indicate this fact.

'Plant Breeder, Petoseed Co., Inc., Bridgeton, NJ 08302-8723. survival and growth of young plants in cold soils are important. In more-southerly regions, melons are often direct-seeded, so that cold germinability may be an important factor in seedling establishment.

Muskmelon genotypes capable of germinating at low (15C) temperatures have been identified (Hutton and Loy, 1991; Nerson et al., 1982). Cold-germinable (CG) lines also showed more rapid early seedling growth than noncold-germinable lines (Hutton, 1988). Since knowledge of the genetics of cold germinability is limited in vegetable species, information regarding low-temperature germination in muskmelon would be useful to breeders. Therefore, we determined the inheritance of cold germinability in muskmelon, using strains previously screened for cold germinability. 

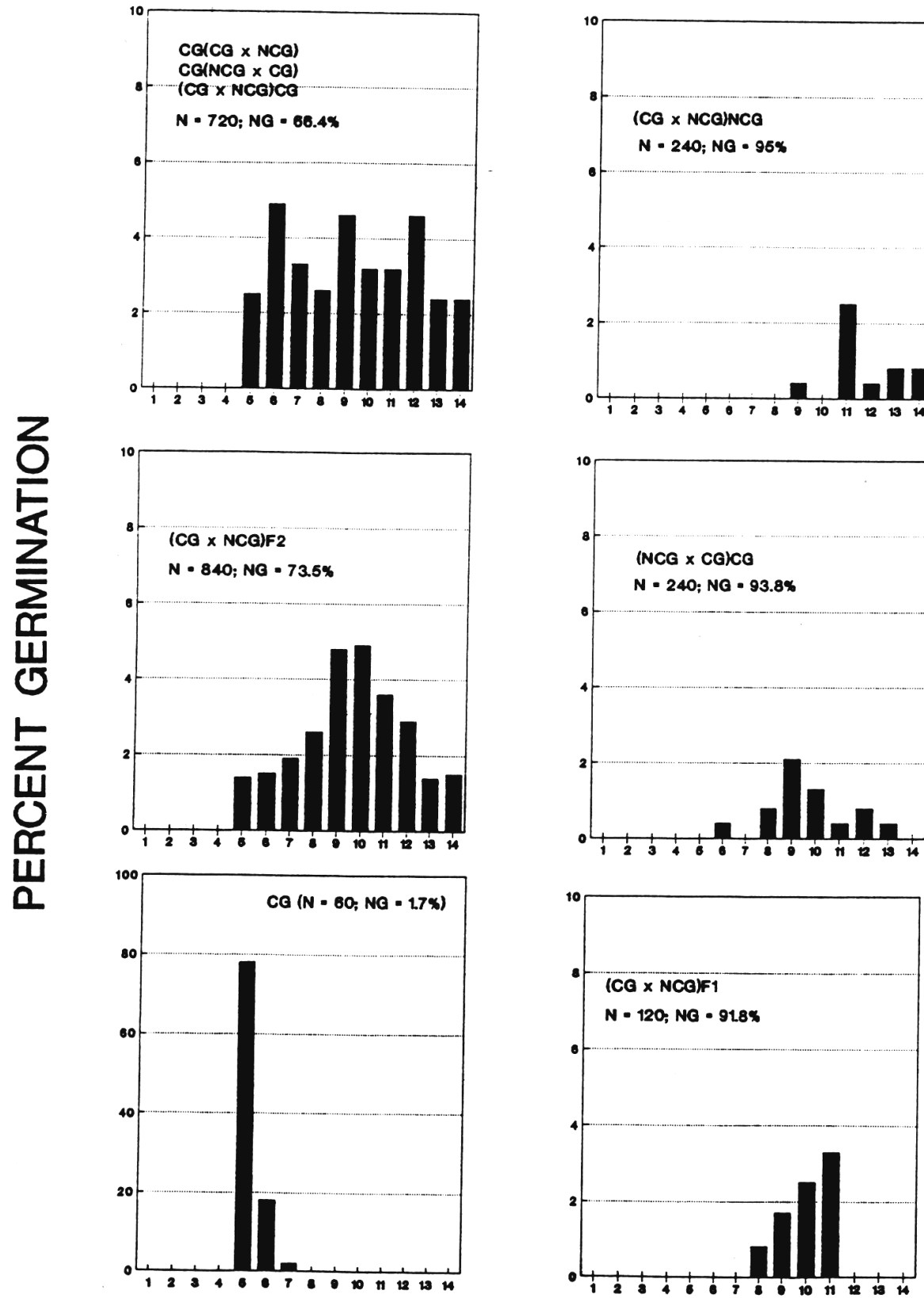

\section{DAYS TO GERMINATION (15C)}

Fig. 1. Percent germination (radicle emergence $>3 \mathrm{~mm}$ ) over time (days) at $15 \mathrm{C}$ for the cold-germinable (CG) line and the $F_{1}$ and segregating families from crosses between PI 126156 (CG) and 'Delicious 51' (NCG) muskmelons. NG = nongerminated.

Two muskmelon cultigens were selected for the inheritance study, based on their germinability at $15 \mathrm{C}$. PI 126156 germinates within 10 days at 15C (Hutton and Loy, 1991) and is referred to as CG. 'Delicious 51' was used as the noncold-germinable (NCG) parent because it shows no radical emergence after 14 days of incubation at $15 \mathrm{C}$. Each parent was inbred for two generations, and selection pressure was applied to the CG line for cold germinability and seedling vigor after 14 days at $15 \mathrm{C}$. The selected plants were grown in a glasshouse, self-pollinated, and the resulting seed subjected to an additional cycle of selection. Seed of the NCG cultigen were incubated for 14 days at $15 \mathrm{C}$, at which time no seed had germinated. Seed were transferred to a 28C incubator and, after 96 $\mathrm{h}$, the most vigorous seedlings were selected, transplanted to a glasshouse, selfpollinated, and the selection cycle repeated.

During Fall 1986, CG and NCG second generation lines were grown in a glasshouse and reciprocal $F_{1}$ crosses were made. Seed of parental lines and reciprocal $F_{1}$ hybrids were sown into Jiffy 7 peat pellets and transplanted into the field in Spring 1987 to produce seed of the parental lines, reciprocal
$\mathrm{F}_{1} \mathrm{~s}$, and the following segregating generations: $F_{2}$ seed from each $F_{1}$ and reciprocal $\mathrm{BC}_{1}$ s. Seed of mature fruit were harvested, fermented 4 days in open jars, rinsed with tap water, and dried in a forced-air dryer at room temperature $(\approx 30 \mathrm{C})$. Dry seed from individual fruit were stored at room temperature (22 to WC) for at least 5 months to minimize seed dormancy. Seedlots derived from up to five fruit were bulked for $\mathrm{F}_{2}$ and $\mathrm{BC}$ populations before germination experiments were started.

The germination-inheritance experiment was conducted at $15 \mathrm{C}$ in a Percival E-30B growth chamber (Percival, Boone, Iowa). Seed treated with Captan (Blue Ribbon Protector-2, Agway, Syracuse, N.Y.) were germinated in $25 \times 100 \mathrm{~mm}$ plastic petri dishes (15 seeds per dish) lined with absorbent wadding (Curity No. 7067, Atlantic Healthcare Products Div., Westbrook, Maine) that was saturated with $12 \mathrm{ml}$ prechilled $\mathrm{dH}_{2} \mathrm{O}$. A randomized complete-block design with four replications was used, with each set of petri dishes randomly arranged in each of four plastic germinating boxes $(27 \times 37 \times$ $16 \mathrm{~cm})$. Boxes were systematically rotated within the growth chamber each day to minimize effects of temperature variation. Seed populations for each replication or box were as follows: 15 parental lines, $30 \mathrm{~F}_{1} \mathrm{~s}, 210$ $\mathrm{F}_{2} \mathrm{~s}$, and $60 \mathrm{BCs}$.

Seed germination was recorded daily for 14 days. A seed was considered germinated when its radicle was longer than $3 \mathrm{~mm}$. After 14 days, dishes were transferred to room temperature (RT; 22 to $25 \mathrm{C}$ ) to determine germinability of those seed that failed to germinate at $15 \mathrm{C}$. The combined germination at $15 \mathrm{C}$ and RT exceeded $85 \%$ for most seed populations.

Seed populations segregating for cold germinability could be grouped into three classes: 1) seed germinating as rapidly as the $C G$ parent, 2) seed germinating within 14-day incubation period but not germinating as quickly as the CG parent, and 3) seed failing to germinate within 14 days, as with the NCG parent. The lack of a variance component for the latter class and segregating populations as a whole precluded estimates of heritability and partitioning of genetic variance for cold germinability.

The CG line derived from PI 126156 exhibited both rapid and a high percentage of germination $(98 \%$ by day 7 ) at $15 \mathrm{C}$ (Table 1, Fig. 1). Seed of the NCG line derived from 'Delicious 51' failed to germinate after 14 days at $15 \mathrm{C}$. Segregating seed populations derived from crosses between the CG and NCG lines exhibited varying degrees of cold germinability; however, no population approached the cold germinability of the CG parent (Table 1, Fig. 1).

There were significant differences in cold germinability between seed populations derived from reciprocal crosses of CG and NCG lines (Table 1). $\mathrm{F}_{1}$ seed from CG $\times \mathrm{NCG}$ gave $8.3 \%$ germination as compared to $0.8 \%$ germination for $\mathrm{NCG} \times \mathrm{CG}$. In segregating BC populations with $\mathrm{CG}$ cytoplasm and $3 / 4$ of the nuclear genome derived from the $\mathrm{CG}$ 
Table 1. Population size, number of cold-germinable (CG) seed, and percent germination at $15 \mathrm{C}$ for seed populations derived from crosses between CG and noncold-germinable (NCG) muskmelon lines.

\begin{tabular}{|c|c|c|c|}
\hline \multirow[b]{2}{*}{ Pedigree } & \multicolumn{2}{|c|}{ Seed (no.) } & \multirow{2}{*}{$\begin{array}{c}\text { Germination at } \\
15 \mathrm{C}(\%)^{z}\end{array}$} \\
\hline & Population & Germinated $^{\mathbf{z}}$ & \\
\hline $\begin{array}{l}\text { Parents } \\
\text { CG }\end{array}$ & 60 & $59-$ & 98.3 \\
\hline $\begin{array}{c}\text { NCG } \\
F_{1} \text { crosses }\end{array}$ & 60 & 0 & 0 \\
\hline CG $\times$ NCG & 120 & 10 & 8.3 \\
\hline $\begin{array}{r}\text { NCG } \times C G \\
F_{2} \text { population }\end{array}$ & 120 & 1 & 0.8 \\
\hline$(C G \times N C G) \otimes$ & 840 & 223 & 26.5 \\
\hline$(\mathrm{NCG} \times \mathrm{CG}) \otimes$ & 840 & 15 & 1.8 \\
\hline $\begin{array}{l}\text { Backcross population } \\
\text { (CG } \times \text { NCG)CG }\end{array}$ & 240 & 86 & 35.8 \\
\hline$(\mathrm{NCG} \times \mathrm{CG}) \mathrm{CG}$ & 240 & 15 & 6.3 \\
\hline $\mathrm{CG}(\mathrm{CG} \times \mathrm{NCG})$ & 240 & 65 & 27.1 \\
\hline CG(NCG x CG) & 240 & $90-$ & 37.5 \\
\hline$(C G \times N C G) N C G$ & 240 & $12-$ & 5.0 \\
\hline$(\mathrm{NCG} \times \mathrm{CG}) \mathrm{NCG}$ & 240 & 0 & 0 \\
\hline $\begin{array}{l}\text { NCG(CG } \times \text { NCG }) \\
\text { NCG(NCG } \times \text { CG })\end{array}$ & $\begin{array}{l}240 \\
240\end{array}$ & $\begin{array}{l}\mathbf{0} \\
\mathbf{0}\end{array}$ & $\begin{array}{l}\mathbf{0} \\
\mathbf{0}\end{array}$ \\
\hline
\end{tabular}

${ }^{2}$ Germination scored as radicle emergence $>3 \mathrm{~mm}$.

Ns,*,**,***Nonsignificant or significant at $P=0.05,0.01$ and 0.001 , respectively, by paired $t$ tests.

Table 2. Inheritance of low-temperature germination ${ }^{2}$ in $F_{2}$ and backcross populations derived from crosses between PI 126156 (cold-germinable; CG) and 'Delicious 51' (noncold-germinable; NCG) muskmelons. Chi-square probabilities are given for models hypothesizing either three or four homozygous recessive genes for conferring cold tolerance in the CG parent.

\begin{tabular}{|c|c|c|c|c|c|c|}
\hline \multirow[b]{2}{*}{ Crosses } & \multirow{2}{*}{$\begin{array}{l}\text { Population } \\
\text { size }\end{array}$} & \multirow{2}{*}{$\begin{array}{c}\text { Cold } \\
\text { germinabley } \\
\text { (no.) }\end{array}$} & \multicolumn{4}{|c|}{ Model } \\
\hline & & & 3-gene & 4-gene & 3-gene & 4-gene \\
\hline & & & \multicolumn{2}{|c|}{ Expected } & \multicolumn{2}{|c|}{$x^{2}$ probability } \\
\hline $\begin{array}{l}(C G \times N C G) \otimes \\
\text { CG(NCG } \times \text { CG) } \\
\text { CG(CG } \times \text { NCG) } \\
(C G \times N C G) C G \\
\text { Total (BC) }\end{array}$ & $\begin{array}{l}840 \\
240 \\
240 \\
240 \\
720\end{array}$ & $\begin{array}{l}24 \\
21 \\
14 \\
18 \\
53\end{array}$ & $\begin{array}{l}13.1 \\
30.0 \\
30.0 \\
30.0 \\
90.0\end{array}$ & $\begin{array}{r}3.3 \\
15.0 \\
15.0 \\
15.0 \\
45.0\end{array}$ & $\begin{array}{l}<0.01 \\
0.05-0.1 \\
<0.01 \\
0.01-0.05 \\
<0.001\end{array}$ & $\begin{array}{l}<0.001 \\
0.1-0.2 \\
0.7-0.9 \\
0.3-0.5 \\
0.2-0.3\end{array}$ \\
\hline
\end{tabular}

${ }^{2}$ Germination scored as radicle emergence $(>3 \mathrm{~mm})$ at $15 \mathrm{C}$.

yCG class of seed germinating as rapidly as the CG parent (by day 5 or 6 ).

xProbability for homogeneity $\chi^{2}$ of three BC populations was $0.3-0.5$.

parent $[\mathrm{CG}(\mathrm{CG} \times \mathrm{NCG}), \mathrm{CG}(\mathrm{NCG} \times \mathrm{CG})$ and $(\mathrm{CG} \times \mathrm{NCG}) \mathrm{CG}], 27 \%$ to $36 \%$ of the seed had germinated at $15 \mathrm{C}$ by day 14 . In contrast, in the backcross $(\mathrm{NCG} \times \mathrm{CG}) \mathrm{CG}$, with the same nuclear genetic component as the populations above, but with NCG cytoplasm, only $6.3 \%$ of the seed showed some degree of cold germinability. None of the three BC seed populations with NCG cytoplasm and $1 / 4$ of the nuclear genome derived from the CG parent germinated at $15 \mathrm{C}$; whereas, $5 \%$ germinated in the comparable $\mathrm{BC}$ population having CG cytoplasm (Table 1). Likewise, $\mathrm{F}_{2}$ seed from $(\mathrm{NG} \times \mathrm{NCG}) \otimes$ gave $26.5 \%$ germination at $15 \mathrm{C}$, but seed from the reciprocal $\mathrm{F}_{2}$ with $\mathrm{NCG}$ cytoplasm gave only $1.8 \%$ germination. The results therefore strongly indicate a maternal component in cold germinability of the CG line derived from PI 126156. Maternal effects conferring some cold germinability or sprouting ability have been reported in other uted $3 / 4$ of the nuclear genome. Recombination of nuclear genes for cold germinability in the presence of NCG cytoplasm [ $\mathrm{NCG} \times$ $\mathrm{CG}) \otimes$ and $(\mathrm{NCG} \times \mathrm{CG}) \mathrm{CG}]$ resulted in populations with low germinability $(1.8 \%$ and $6.3 \%$, respectively) at $15 \mathrm{C}$, in contrast, recombination of CG nuclear genes in populations with $\mathrm{CG}$ cytoplasm [(CG $\times \mathrm{NCG}) \otimes$, $\mathrm{NG}(\mathrm{NG} \times \mathrm{NCG})$, and $(\mathrm{NG} \times \mathrm{NCG}) \mathrm{NG}]$ gave relatively high percentages of germination (26.5\% to $37.5 \%)$ at $15 \mathrm{C}$.

We fit our data to Mendelian inheritance models by determinating the percentage of progeny (with CG cytoplasm) in segregating populations that germinated as rapidly (within 6 days) as the CG parent and equating that class as carrying the homozygous recessive complement of genes for cold germinability.

Only $\approx 3 \%$ of $\mathrm{F}_{2}$ seed from (CG $\times$ NCG)@ germinated as rapidly as the CG line (Table 2). These results fit neither a two-gene $(6.25 \%$ homozygous recessive) nor a three-gene (1.56\% homozygous recessive) model but suggest that a maximum of three recessive genes is involved in cold germinability. However, backcross progeny with CG cytoplasm [ $(\mathrm{CG} \times \mathrm{NCG}) \mathrm{CG}, \mathrm{CG}(\mathrm{CG} \times \mathrm{NCG})$, and $\mathrm{CG}(\mathrm{NCG} \times \mathrm{CG})]$ had between $6 \%$ to $9 \%$ rapidly germinating recombinants, values consistent with a four-recessive-gene model. We cannot explain the different interpretations of the backcross and $F_{2}$ segregation data with our simple inheritance models. Transgressive segregation was not detected in our seed populations (Fig. 1), indicating that the NCG parent did not contribute genes for cold germinability.

Nuclear genes have been implicated in lowtemperature germinability of other species (De Vos et al., 1981; El Hassan, 1971; Ng and Tigchelaar, 1973). In muskmelon, Kubicki (1962) reported that the capacity of muskmelon to germinate in cold soils was a dominant trait; the preliminary results of Nerson and Staub (1989) likewise suggested that cold germinability in 'Persian 202' was due to dominant gene(s). Therefore, differences in the genetic basis of cold tolerance in muskmelon likely exist and may involve recessive and dominant genes. Several accessions of muskmelon with varying degrees of cold tolerance have now been identified (Hutton, 1988). It may be possible for breeders to select for more extreme cold tolerance by intercrossing known cold-tolerant lines, thereby producing different gene combinations for cold tolerance.

Selection for cold germinability presents some problems. We were unsuccessful in trying to establish the genetic basis of cold germinability in crosses of PI 126156 to 'Minnesota Midget', a cultivar with moderate levels of cold tolerance (Hutton, 1988). 'Minnesota Midget' had the cold-tolerant cytoplasmic factor but showed considerable instability in cold germinability among different seed lots. Proper harvesting and handling of seed are critical for evaluating germinability (Edwards et al., 1986). We have observed that fresh seedlots of muskmelon, especially those harvested from greenhouse-grown plants, often exhibit a dormancy (unpub- 
lished data), and the dormancy is more evident at low than at high temperatures, as has been observed in cucumber (Edwards et al., 1986).

In the present study we equated cold germinability with radicle emergence at $15 \mathrm{C}$ because seeds sprouting most rapidly at $15 \mathrm{C}$ also showed the most rapid development to the cotyledon stage at 15C (Hutton, 1988). Also, in a comparison of three CG lines (including PI 126156) and two NCG lines, a highly significant correlation $(r=0.88)$ was found between germinability at $15 \mathrm{C}$ and relative growth rate of young plants at $15 \mathrm{C}$ (Hutton, 1988). The greater growth rate of the $\mathrm{CG}$ lines at $15 \mathrm{C}$ may have been due to factors other than genes for cold tolerance per se (e.g., large seed and seedlings), but nonetheless, the CG lines may prove to be valuable germplasm for developing muskmelon strains with better capability to ger- minate and survive in suboptimal climates than NCG lines.

\section{Literature Cited}

Cal, J.P. and R.L. Obendorf. 1972. Inhibitional chilling injury in Zea mays L. altered by initial kernel moisture and maternal parent. Crop Sci. 12:369-373.

Christiansen, M.N. and C.F. Lewis. 1973. Reciprocal differences in tolerance to seed-hydration chilling in $\mathrm{F}_{1}$ progeny of Gossypium hirsutum L. Crop Sci. 13:210-212.

De Vos, D.A., R.R. Hill, Jr., R.W. Hepler, and D.L. Garwood. 1981. Inheritance of low temperature sprouting ability in $\mathrm{F}_{1}$ tomato crosses. J. Amer. Soc. Hort. Sci. 106:352-355.

Edwards, M.D., R.L. Lower, and J.E. Staub. 1986. Influence of seed harvesting and handling procedures on germination of cucumber seeds. J. Amer. Soc. Hort. Sci. 111:507-512.

El Hassan, G.M. 1971. Inheritance studies of low and high temperature germination of tomato. $\mathrm{PhD}$ Diss. Abstr. 72-9889, Univ. of California, Davis.
Hutton, M.G. 1988. Genetics and physiology of cold tolerance in muskmelon (Cucumis melo L.). PhD Diss., Univ. of New Hampshire, Durham. Hutton, M.G. and J.B. Loy. 1991. Muskmelon cultigens evaluated for low-temperature germinability. HortScience 26:1333.

Kubicki, B. 1962. Inheritance of some characters in muskmelons (Cucumis melo L.). Genet. Polon. 3:265-275.

Marani, A. and J. Dag. 1962. Inheritance of the ability of cotton seeds to germinate at low temperature in the first generation. Crop Sci. 2:243245.

Nerson, H. and J.E. Staub. 1989. Low temperature germination in muskmelon is dominant. Cucurbit Genet. Coop. Rpt. 12:50-51.

Nerson, H., D.J. Cantliffe, H.S. Paris, and Z. Karchi. 1982. Low-temperature germination of birdsnest-type muskmelons. HortScience 17:339340.

Ng, T.J and E.C. Tigchelaar. 1973. Inheritance of low temperature seed sprouting in tomato. J. Amer. Soc. Hort. Sci. 98:314-316. 